https://doi.org/10.19195/0524-4544.329.39

\author{
MONIKA MICHALUK-MAZUREK \\ ORCID: 0000-0002-8092-3483 \\ Uniwersytet Gdański \\ monika.michaluk@poczta.fm
}

\title{
Zrównoważony system ochrony zdrowia rozważania na tle aktualnej polityki lekowej państwa
}

\begin{abstract}
Abstrakt: Trwały i zrównoważony rozwój jest elementem wszystkich polityk Unii Europejskiej, a więc i polityk krajowych państw członkowskich, w tym Polski. Jego integralną i istotną częścią jest zdrowie publiczne. Bezpieczeństwo zdrowotne obywateli jest celem przede wszystkim polityki zdrowotnej państwa oraz składającej się na nią polityki lekowej. Narzędziem, za pomocą którego polityki te są realizowane, jest system ochrony zdrowia, którego sprawność zależna jest nadto od innych systemów funkcjonujących w państwie; tworzy on bowiem integralną część całego systemu gospodarczego, politycznego i społecznego. Tylko balansujący potrzeby zdrowotne, możliwości finansowe i gospodarcze państwa, oraz udział podmiotów niepublicznych system może dać sukces w dziedzinie zdrowia publicznego. Braki w tym zakresie szczególnie widoczne są w ostatnim czasie w zakresie bezpieczeństwa lekowego polskich obywateli. Zasadniczym celem artykułu będzie więc ocena postępów legislacyjnych w kwestiach istotnych dla polityki lekowej, a w konsekwencji całej polityki zdrowotnej kraju i zdrowia publicznego jako komponentu zrównoważonego rozwoju.
\end{abstract}

Słowa kluczowe: zrównoważony rozwój, polityka zdrowotna, polityka lekowa, system ochrony zdrowia.

[...] system zdrowotny może być szeroko zdefiniowany jako spójna całość, której liczne, powiązane między sobą części wspólnie oddziałując wpływają (pozytywnie) na stan zdrowia populacji*

* Definicja systemu zdrowotnego przedstawiona w dokumencie Światowej Organizacji Zdrowia - por. B.M. Kleczkowski, M.I. Roemer, A. van der Werff, National health systems and their reorientation towards health for all. Guidance for policy making, WHO, Geneva 1984, [w:] C. Włodarczyk, S. Poździoch, Systemy zdrowotne. Zarys problematyki, Kraków 2001, s. 28. 


\section{Wstęp}

Zdrowie w dzisiejszych czasach jest istotnym elementem rozwoju społeczno-gospodarczego społeczeństwa — to, z jednej strony, określona wartość jednostki i społeczeństwa, niemożliwa do oszacowania w pieniądzu, z drugiej zaś, pewien zasób, dzięki któremu jednostki i społeczeństwa osiągają rezultaty ekonomiczne ${ }^{1}$. Zdrowie i życie ludzi to najważniejsze prawnie chronione dobro, a jednocześnie element bezpieczeństwa publicznego. Zgodnie z art. 68 Konstytucji $\mathrm{RP}^{2}$, każdy jest uprawniony do ochrony zdrowia, a treścią tego prawa jest możliwość korzystania z systemu ochrony zdrowia ukierunkowanego funkcjonalnie na zwalczanie i zapobieganie chorobom. Decydującego znaczenia nabiera w związku z tym prawidłowe określenie przez ustawodawcę sfery organizacyjnej związanej z precyzyjnym, jednoznacznym i funkcjonalnym skonstruowaniem systemu ochrony zdrowia ${ }^{3}$.

Słabości naszego krajowego systemu ochrony zdrowia pokazują, że ogromnym wyzwaniem jest osiągnięcie stanu równowagi pomiędzy wszystkimi elementami nań się składającymi, a kolejne próby osiągnięcia takiego stanu podejmowane przez właściwe władze nie są efektywne. Konieczne jest przeprowadzenie wielu zmian mających na celu uzdrowienie relacji między składowymi systemu zdrowotnego, począwszy od zmian systemowych dotyczących organizacji ochrony zdrowia, poprzez zmiany dotyczące zasad finansowania ukierunkowanego na płacenie za efekty zdrowotne, a nie za wykonanie procedury medycznej, poprawy dostępu do świadczeń medycznych oraz dostępu do nowoczesnych terapii. W ostatnim czasie jednak prawdziwy kryzys dotknął bezpieczeństwa lekowego polskich obywateli ${ }^{4}$. Wskutek nieustających zmian demograficznych oraz epidemiologicznych popyt na leki stale rośnie. Rolą państwa jako głównego realizatora zadań publicznych z zakresu ochrony zdrowia jest zaś zapewnienie ciągłości ich dostaw. Odpowiedzialność państwa w tym względzie obejmuje w szczególności normodawstwo w zakresie produktów leczniczych ${ }^{5}$. Zasadniczym celem artykułu będzie więc ocena postępów legislacyjnych w kwestiach istotnych dla polityki lekowej, a w konsekwencji całej polityki zdrowotnej kraju i zdrowia publicznego jako komponentu zrównoważonego rozwoju.

1 J. Leowski, Rola i miejsce państwa w systemie ochrony zdrowia, „Prawo i Medycyna” 2000, nr 6-7, s. 21.

${ }^{2}$ Konstytucja Rzeczypospolitej Polskiej z dnia 2 kwietnia 1997 r., Dz.U. Nr 78, poz. 483.

3 Por. L. Bosek, [w:] Komentarz do art. 68 Konstytucji RP, red. M. Safjan, L. Bosek, t. 1, 2016, pkt I.5, Legalis; nadto wyrok TK z dnia 7 stycznia 2004 roku, K 14/03 OTK-A 2004, nr 1, poz. 1 .

${ }^{4}$ Coraz więcej Polaków boi się o brak leków w aptekach, a wśród obawiających się aż 74\% doświadczyło takiej sytuacji, co wynika z badania opinii publicznej przeprowadzonego na zlecenie Polskiego Związku Pracodawców Przemysłu Farmaceutycznego w kwietniu 2019 roku, 64\% twierdzi, że czułoby się bezpieczniej, gdyby większość leków dostępnych w aptekach była produkowana w Polsce - badanie opinii publicznej wykonane na zlecenie Polskiego Związku Pracodawców Przemysłu Farmaceutycznego w kwietniu 2019 roku.

5 Por. R. Kruszyński, Obrót detalicznymi lekami. Zagadnienia prawne, Warszawa 2014, s. 14. 


\section{Zrównoważony system ochrony zdrowia}

Każdy z systemów ochrony zdrowia sprowadzić można do dwóch zasadniczych sfer działań - opieki zdrowotnej rozumianej jako medycyna lecznicza (prewencja, leczenie, naprawa, rehabilitacja, opieka terminalna) oraz ochrony zdrowia rozumianej jako działania na rzecz zdrowia realizowane zarówno przez podmioty wyspecjalizowane w służbie zdrowia publicznego, służby medyczne, jak i inne sektory życia społeczno-gospodarczego, odpowiedzialne za stwarzanie społeczeństwu właściwych warunków zdrowotnych ${ }^{6}$. Za pomocą tego narzędzia, jakim jest system ochrony zdrowia, realizowana jest polityka zdrowotna państwa, w ramach której władze publiczne powinny czuwać nad stanem zdrowia ludności ${ }^{7}$. Miejsce i rola systemu ochrony zdrowia w ogólnym systemie organizacyjnym państwa to jedne z najistotniejszych kryteriów, na podstawie których obywatele mogą oceniać efektywność oraz przydatność służb publicznych. Sprawność tego systemu zależna jest nadto od innych systemów funkcjonujących w państwie - tworzy on integralną część całego systemu gospodarczego, politycznego i społecznego, których właściwe zorganizowanie może zapewnić realizację potrzeb zdrowotnych obywateli ${ }^{8}$. Na organizację narodowego systemu zdrowotnego wpływ mają warunki polityczne, ekonomiczne, kulturowe, etyczno-moralne. Nadto ważnym elementem składowym tego systemu jest także środowisko przyrodnicze, na które składają się czynniki fizyczne, chemiczne, biologiczne, tworzące razem ze środowiskiem społecznym system ekologiczny'.

Takie elementy, jak rozwój gospodarczy, spójność społeczna, ochrona środowiska, zdrowie publiczne współfunkcjonują i wzajemnie się uzupełniają — taka jest wizja zrównoważonego rozwoju w strategii Unii Europejskiej, w której wytyczone zostały długoterminowe jej kierunki ${ }^{10}$. Trwały i zrównoważony rozwój jest elementem wszystkich polityk UE ${ }^{11}$. W pierwszej zasadzie deklaracji z Rio de Janeiro w sprawie środowiska i rozwoju z 1992 roku $^{12}$ wskazano, że: ,istoty ludzkie są $\mathrm{w}$ centrum zainteresowania w procesie zrównoważonego rozwoju. Mają prawo do zdrowego i twórczego życia w harmonii z przyrodą". Bezsprzecznie zatem ran-

${ }^{6}$ Por. H. Izdebski, System ochrony zdrowia, [w:] Prawo publiczne ochrony zdrowia, red. M. Dercz, H. Izdebski, T. Rek, Warszawa 2013, s. 33-34.

7 Por. ibidem, s. 32. Według podejścia behawioralnego z kolei polityka zdrowotna jest jedną z trzech zasadniczych części systemu zdrowotnego, a poza nią są jeszcze system medyczny i zachowania zdrowotne ludzi. Por. C. Włodarczyk, S. Poździoch, Systemy zdrowotne. Zarys problematyki, Kraków 2001, s. 53.

8 M. Dercz, Samorzad terytorialny w systemie ochrony zdrowia, Warszawa 2005, s. 9, 40.

${ }^{9}$ K. Włoch, [w:] Zdrowie publiczne, red. M. Latalski, Lublin 1999, s. 199.

10 Strategia na rzecz inteligentnego i zrównoważonego rozwoju sprzyjającego włączeniu społecznemu, przyjęta przez Komisję Europejską w celu stymulowania rozwoju gospodarki europejskiej — Europa 2020, https://ec.europa.eu/eu2020 (dostęp: 29.09.2019).

11 Traktat o funkcjonowaniu Unii Europejskiej, art. 26, Dz.U. C 326, 26/10/2012 P. 00010390.

12 https://bs.sejm.gov.pl (dostęp: 29.09.2019). 
ga, jaką nadaje się problematyce zdrowia w koncepcji zrównoważonego rozwoju państw i społeczeństw, jest nie do przecenienia ${ }^{13}$. Dlatego też systemy ochrony zdrowia muszą w tę koncepcję się wpisywać, a zarazem dawać gwarancję jej realizacji. Przez zrównoważony system ochrony zdrowia należy rozumieć taki, który normuje i balansuje potrzeby zdrowotne społeczeństwa, możliwości gospodarcze i finansowe państwa, angażuje do udziału społeczeństwo i podmioty niepubliczne, opiera się na innowacyjności i postępie. Tylko osiągnięcie równowagi pomiędzy wszystkimi istotnymi dla tego systemu, jego odbiorców, uczestników i dla otoczenia tego systemu, elementami, da gwarancję bezpieczeństwa zdrowotnego obywateli.

\section{Polityka lekowa państwa - aktualne wyzwania}

Polityka zdrowotna państwa opiera się na działaniach w zakresie organizacji i działania systemu ochrony zdrowia, kształtowania odpowiedniego stylu życia oraz ochrony ekosystemu (środowiska), w którym żyje człowiek ${ }^{14}$. Integralną częścią polityki zdrowotnej oraz systemu ochrony zdrowia jest polityka lekowa — jest ona zarazem elementem innych polityk kraju (społecznej, finansowej). Obecnie mija rok, od czasu kiedy Rada Ministrów przyjęła dokument o nazwie Polityka lekowa państwa 2018-2022 $2^{15}$, w którym określone zostały priorytety działań rządu w zakresie gospodarowania lekami. Dokument ten wytycza średnio- i długoterminowe cele stawiane uczestnikom rynku farmaceutycznego oraz identyfikuje główne narzędzia umożliwiające ich osiągnięcie. Głównym celem tej polityki jest przejrzysty oraz racjonalny system refundacji i zapewnienie szerokiego dostępu do produktów leczniczych. Obecnie, jednym z najważniejszych zadań stojących przed rządzącymi, związanych z wdrażaniem Polityki lekowej państwa, jest nowelizacja ustawy refundacyjnej, która wprowadziłaby ułatwienia w podejmowaniu decyzji w procesach refundacyjnych. Jednym z oczekiwanych przez przedsiębiorców rezultatów jest wprowadzenie rozwiązań zachęcających do rozwoju produkcji i możliwości inwestowania w kraju. Chodzi w szczególności o stosowanie szerszej gamy instrumentów dzielenia ryzyka ${ }^{16}$, wdrażanie

13 Por. E. Mazur-Wierzbicka, Zdrowie publiczne jako element zrównoważonego rozwoju - analiza komparatywna. Polska na tle Unii Europejskiej, „Zeszyty Naukowe Uniwersytetu Ekonomicznego w Katowicach" 2017, nr 310, s. 1.

14 C. Włodarczyk, Polityka zdrowotna w społeczeństwie demokratycznym, Łódź-Kraków 1996, s. 34-37.

15 https://www.gov.pl/documents/292343/436711/POLITYKA_LEKOWA_PAŃSTWA_2018-2022_12072018_v76.pdf/040bcf05-b07d-703d-0368-ccdc075f7c3e- (dostęp: 29.09.2019).

16 Por. art. 11 ust. 5 ustawy refundacyjnej; M. Świerczyński, Obrót produktami leczniczymi oraz wymagania dotyczace podmiotów prowadzacych obrót, [w:] Prawo farmaceutyczne. Zagadnienia regulacyjne i cywilnoprawne, red. M. Krekora, E. Traple, Warszawa 2008, s. 442. 
value based healthcare ${ }^{17}$ czy early advice ${ }^{18}$, a przede wszystkim innowacyjnego/ refundacyjnego trybu rozwoju (dalej: RTR) ${ }^{19}$.

W uzasadnieniu do ustawy z dnia 12 maja 2011 roku o refundacji leków, środków spożywczych specjalnego przeznaczenia żywieniowego oraz wyrobów medycznych ${ }^{20}$ (dalej: ustawa o refundacji) podkreślono, że celem tej ustawy jest racjonalizacja wydatków na refundację oraz zwiększenie dostępności produktów leczniczych a w szczególności dostępności innowacyjnych terapii. Zwiększaniu tej dostępności ma służyć między innymi określanie kryteriów oraz interesów branych pod uwagę przez Ministra Zdrowia przy wydawaniu rozstrzygnięcia refundacyjnego. Kryteria te, które zawarte są w art. 12 i 13 tej ustawy, określają sposób realizacji ogólnego celu refundacji. Przesłanki wymienione w art. 13 wskazują nadto na obowiązek równoważenia interesów podmiotów, których dotyczy refundacja - świadczeniobiorców oraz przedsiębiorców zajmujących się obrotem i wytwarzaniem objętych refundacją produktów oraz nakazujące wzięcie pod uwagę wpływu na budżet płatnika publicznego ${ }^{21}$.

Wprowadzenie RTR zostało zapisane w przyjętej przez rząd Polityce lekowej państwa na lata 2018-2022 jako narzędzie realizacji jednego z celów wyznaczonych w tym dokumencie - rozwoju krajowego przemysłu farmaceutycznego, który uważany jest przez polski rząd za strategiczny i priorytetowy ${ }^{22}$. Pomysł wprowadzenia systemu preferencji dla firm produkujących leki w Polsce przy negocjowaniu cen produktów refundowanych pojawił się już w 2016 roku, a jego pierwotnym celem było przyznanie preferencji refundacyjnych dla firm, które już produkują leki w Polsce lub zdecydują się uruchomić tu produkcję $e^{23}$. Z jednej strony instrument ten wspierałby przedsiębiorczość w sektorze farmaceutycznym,

17 Pojęcie value based healthcare oznacza model świadczenia opieki zdrowotnej, w którym świadczeniodawcy otrzymują wynagrodzenie na podstawie wyników zdrowotnych pacjentów w odróżnieniu od podejścia opartego na wynagradzaniu świadczeniodawców w zależności od liczby świadczonych usług opieki zdrowotnej.

18 Pojęcie early advice oznacza wprowadzenie usługi merytorycznego wsparcia organu kompetentnego na etapie planowania rozwoju leku, w tym projektowania badań klinicznych (doradztwo naukowe, scientific advice).

19 Prof. Marcin Czech w prezentacji podczas konferencji prasowej z dnia 15 lipca 2019 roku, [w:] J. Czudak, Ważne zadania stojace przed resortem zdrowia, https://liderzyinnowacyjnosci.com/ wazne-zadania-stojace-przed-resortem-zdrowia/ (dostęp: 29.09.2019).

20 Tekst jedn. Dz.U. z 2019 r. poz. 784.

21 Por. M. Pieklak, [w:] Ustawa o refundacji leków, środków spożywczych specjalnego przeznaczenia żywieniowego oraz wyrobów medycznych. Komentarz, red. M. Pieklak, R. Stankiewicz, Warszawa, 2014, s. 137.

22 W maju 2019 roku Ministerstwo Przedsiębiorczości i Technologii opracowało projekt działania RTR i przekazało go Ministrowi Zdrowia, został on jednak przez ten organ odrzucony, co oznacza, że w tej kadencji Sejmu nie zostanie już przyjęty.

${ }^{23}$ Krzysztof Łanda, były wiceminister zdrowia, w wywiadzie z dnia 5 maja 2019 roku z J. Czudak, Nawet najgorszy refundacyjny tryb rozwojowy rtr jest lepszy niż żaden, https://liderzyinnowacyjnosci.com/nawet-najgorszy-refundacyjny-tryb-rozwojowy-rtr-jest-lepszy-niz-zaden/ (dostęp: 29.09.2019). 
z drugiej wpływałby na bezpieczeństwo lekowe obywateli przez uniezależnienie się od producentów zewnętrznych. Obecna struktura polskiego rynku i branży lekowej charakteryzuje się bowiem znaczną przewagą importu nad eksportem. Produkcja leków przez rodzimych przedsiębiorców obniżałaby koszty terapii, co z kolei miałoby wpływ na większy dostęp do nowoczesnego lecenia - to zaś odczuliby bezpośrednio pacjenci i cały system ochrony zdrowia ${ }^{24}$. Założeniem RTR zaś jest premiowanie aktywności inwestycyjnej i produkcyjnej w Polsce. Krajowe firmy mogłyby liczyć przykładowo na przedłużenie decyzji refundacyjnych bez dodatkowych negocjacji oraz zwolnienie z paybacku ${ }^{25}$.

Coraz większy dostęp do leków biologicznych równoważnych powinien poprawiać dostęp do leczenia biologicznego w Polsce. Problemem jest jednak to, że pieniądze zaoszczędzane na refundacji leków, w związku z zastosowaniem instrumentów dzielenia ryzyka, nie są włączane do budżetu przeznaczonego na cele refundacyjne, lecz na inne świadczenia finansowane przez NFZ. Tym samym nie zwiększa to dostępności środków na zakup nowoczesnych terapii. Pieniądze zaoszczędzone na refundacji leków powinny wracać do systemu opieki zdrowotnej i być przeznaczane przez NFZ na zakup nowych terapii, a nie na inne cele, jak choćby podwyżki dla personelu medycznego ${ }^{26}$. Nieprawidłowy przepływ środków pieniężnych to problem, widoczny niestety w każdej sferze systemu ochrony zdrowia, nie tylko w polityce lekowej, a przecież obowiązkiem płatnika jest odpowiedzialne wydatkowanie środków publicznych. Na organach władzy publicznej spoczywa obowiązek stworzenia systemu, który cechuje efektywność kosztowa ${ }^{27}$. Zdrowy obywatel jest dla budżetu państwa zyskiem - niewątpliwie bowiem choroba czy niepełnosprawność generują wysokie koszty. Jednym z zadań systemu ochrony zdrowia jest przecież także ochrona przed finansowymi skutkami chorób ${ }^{28}$, a także zapewnienie starzejącym się społeczeństwom dostępu do terapii lekowych tak, by nie zachwiało to stabilnością finansową systemów ochrony zdrowia.

24 Barbara Misiewicz-Jagielak, wiceprezes PZPPF w wywiadzie: Jesteśmy za wprowadzeniem rtr, https://www.rynekaptek.pl/wywiad/jestesmy-za-wprowadzeniem-rtr,33301.html (dostęp: 29.09.2019).

25 Art. 3 ust. 2 ustawy refundacyjnej. Por. także J. Pacian, [w:] Refundacja leków w Polsce. Wyktadnia przepisów i efekty ich stosowania, red. H. Kaczmarczyk, Warszawa 2015, s. 28. Całkowity budżet na refundację wynosi nie więcej niż 17\% sumy środków publicznych przeznaczonych na finansowanie świadczeń gwarantowanych w planie finansowym Funduszu i jest narzędziem definiującym maksymalną wielkość wydatków płatnika. Po przekroczeniu tego progu w części dotyczącej finansowania świadczeń, o których mowa w art. 15 ust. 2 pkt 14 ustawy o świadczeniach, wskazane podmioty odpowiedzialne, które uzyskały wzrost kwoty refundacji w stosunku do roku poprzedniego, zobowiązane są do partycypowania w wydatkach publicznych na leki poprzez zwrot $100 \%$ kwoty przekroczenia (tak zwany payback).

${ }^{26}$ Irena Rej, prezes Izby Gospodarczej Farmacja Polska, wypowiedź w trakcie debaty z dnia 24 czerwca 2019 roku na konferencji w PAP, https://liderzyinnowacyjnosci.com/leki-biologiczne-sa-tak-samo-wartosciowe-jak-oryginalne-i-innowacyjne/ (dostęp: 29.09.2019).

27 Wyrok TK z dnia 3 stycznia 2004 roku, K 14/03, Dz.U. Nr 5, poz. 37.

28 Por. H. Izdebski, op. cit., s. 32. 
Innym, istotnym z punktu widzenia bezpieczeństwa zdrowotnego obywateli, problemem widocznym $w$ ramach polityki lekowej jest tak zwany odwrócony łańcuch dostaw. Wprowadzenie lepszych możliwości kontroli i ograniczania nielegalnego eksportu leków odnotowano jako sukces w postępach wdrażania zadań z polityki lekowej. Czy tak jest jednak istotnie, skoro odwrócony łańcuch dostaw to wciąż żywy problem? Rozwiązaniem problemu niekontrolowanego wywozu produktów leczniczych miała być ustawa z dnia 9 kwietnia 2015 roku o zmianie ustawy Prawo farmaceutyczne oraz niektórych innych ustaw ${ }^{29}$. Dotychczasowe brzmienie art. 127 ustawy z dnia 6 czerwca 2001 roku Prawo farmaceutyczne (dalej: pf) ${ }^{30}$ zakazywało działań prowadzonych przez apteki polegających na sprzedaży leków niebezpośrednio ludności, ale hurtowniom farmaceutycznym. Ustawa z 2015 roku dodała art. 126b penalizujący zachowanie polegające na zbyciu produktów leczniczych z apteki do hurtowni farmaceutycznej lub innej apteki. Tym samym wydaje się, że możliwe będzie, w przypadku wykonywania takich czynności, uznanie ich za przestępstwo z tego artykułu, jak i nałożenie kary pieniężnej z art. $127 \mathrm{pf}^{31}$. Z kolei czynności hurtowni w ramach odwróconego łańcucha dostaw nie były dotychczas obarczone sankcją, można uznać je jedynie za prowadzenie hurtowni wbrew warunkom zezwolenia w myśl art. $127 \mathrm{pf}^{32}$. Jeśli rozwiązania ustawowe należałoby oceniać $\mathrm{w}$ tej mierze pozytywnie, to $\mathrm{w}$ takim razie szwankuje sfera związana z egzekwowaniem norm karnych zabezpieczających przed tym procederem. Do tak jednoznacznej pozytywnej oceny nowelizacji z 2015 roku zdaniem autorki nie ma jednak podstaw. W dalszym ciągu istnieje pole do nadużyć polegających na niekorzystnej dla systemu ochrony zdrowia i bezpieczeństwa lekowego interpretacji przepisów penalizujących ten proceder. Domagać trzeba się zatem jak najszybszej nowelizacji art. 127 pf, który nie zapewnia dostatecznej ochrony przed stosowaniem odwróconego łańcucha dostaw. Pełna kryminalizacja obejmująca każdy etap procederu polegającego na nielegalnym obrocie produktami leczniczymi, w szczególności odwrócony łańcuch dystrybucji tych produktów, powinna zostać przewidziana w najbliższej nowelizacji ustawy ${ }^{33}$. W projektowanych przez Ministerstwo Sprawiedliwości zmianach w Prawie Farmaceutycznym ${ }^{34}$ taka propozycja już się pojawiła - szeroką kryminalizację uzupełnić ma wprowadzenie do ustępu drugiego tego przepisu sformułowania: „branie udziału w obrocie produktem leczniczym uzyskanym za

29 Dz.U. z 2015 r. poz. 788.

30 Tekst jedn. Dz.U. z 2019 r. poz. 499.

31 J. Stefańczyk-Kaczmarzyk, [w:] Prawo farmaceutyczne. Komentarz, M. Kondrat, Warszawa 2016, s. 1394.

32 Ibidem, s. 1394-1395; wyrok SO w Gliwicach z dnia 13 stycznia 2015 roku, VI Ka 790/14, orzeczenia.ms.gov.pl.

33 Por. L. Wilk, [w:] Prawo farmaceutyczne. Komentarz, red. L. Ogiegło, Warszawa 2018, s. $1130,1151-1152$.

34 Por. ibidem, numer wykazu UD374 — opracowany z własnej inicjatywy MS projekt ustawy o zmianie Prawa Farmaceutycznego i innych ustaw. 
pomocą czynu określonego w ust. 1”35. Obecna kryzysowa sytuacja pokazuje, że zdecydowane poszerzenie zakresu zarówno przedmiotowego, jak i podmiotowego zabronionego zachowania jest konieczne i powinno zostać jak najszybciej wdrożone. Niezrozumiała jest zatem opieszałość w procedowaniu w przedmiocie projektu tych zmian.

\section{Podsumowanie}

Działania legislacyjne są obowiązkiem państwa, jeśli chodzi o zaangażowanie $\mathrm{w}$ funkcjonowanie rynku leków ${ }^{36}$. Ocena postępu prac legislacyjnych zmierzających do budowy i utrzymania zrównoważonego systemu ochrony zdrowia w kraju w kontekście polityki lekowej nie daje jednak satysfakcjonujących wyników. Pożądane rozwiązania nie są wdrażane mimo zagrożenia bezpieczeństwa zdrowotnego obywateli. W tej mierze najistotniejsze jest obecnie wprowadzenie regulacji gwarantujących ciągłość dostaw produktów leczniczych. Jak najszybciej więc powinno dojść do uchwalenia rozwiązań wspierających polski przemysł farmaceutyczny — chodzi o optymalizację procesów regulacyjnych, wprowadzenie realnych zachęt dla przemysłu farmaceutycznego — konkretnie w postaci RTR. System refundacji powinien wspierać aktywność inwestycyjną i rozwój polskiej gospodarki. Równie pilnie powinno dojść do podjęcia przez ustawodawcę działań legislacyjnych zmierzających do nowelizacji art. $127 \mathrm{pf}$.

Zrównoważony system ochrony zdrowia to pacjent, jakość, wartość, partnerstwo, kontrolowany i ukierunkowany na pacjenta przepływ środków finansowych, wsparcie przez przedsiębiorców niepublicznych oraz wsparcie dla nich, innowacyjność, gwarancja ciągłości dostaw i świadczenia usług zdrowotnych. Do budowy nowoczesnego systemu ochrony zdrowia, a następnie stabilnej jego działalności, konieczna jest współpraca wszystkich jego uczestników, a nadto wola administracji publicznej w zakresie każdej z polityk składających się na politykę zdrowotną kraju.

Zrównoważone systemy ochrony zdrowia to wyzwanie na najbliższe lata dla wielu rządów, w tym dla polskiej polityki zdrowotnej. Zrównoważony system zdrowotny to także wyzwanie nie tylko dla państwa, lecz także dla podmiotów niepublicznych - przedsiębiorców. W odniesieniu do przedsiębiorców z sektora farmaceutycznego, stwierdzić należy, że po ich stronie istnieje gotowość do podjęcia tego wyzwania, jakim jest realizacja koncepcji zrównoważonego roz-

$35 \mathrm{~W}$ projektowanych zmianach ustęp pierwszy art. 127 pf brzmi: „kto wbrew przepisom ustawy nabywa, zbywa, przywozi, wywozi, przewozi lub przechowuje produkt leczniczy, podlega karze pozbawienia wolności od 3 miesięcy do lat 5".

36 P. Kiviniemi, Riding the Waiver, „Mlex Magazine” 2012, nr 9, s. 32. 
woju systemu, w którym funkcjonują ${ }^{37}$. Nie można, niestety, tak jednoznacznych wniosków wysunąc w odniesieniu do podmiotów odpowiedzialnych za realizację zadania publicznego, jakim jest ochrona zdrowia ze strony państwa.

Podejmowanie wszechstronnych i zorganizowanych działań mających na celu profilaktykę, poprawę i przywracanie stanu zdrowia wymaga zaś współpracy podmiotów publicznych z podmiotami niepublicznymi i zaangażowania właściwych przedstawicieli władzy ${ }^{38}$. Również widoczny na rynku zdrowia patriotyzm ekonomiczny po stronie obywateli jako świadomych konsumentów ${ }^{39}$ dokonujących odpowiedzialnych wyborów i częściej sięgających po lek rodzimego pochodzenia $^{40}$ jest działaniem na rzecz zrównoważonego rozwoju systemu ochrony zdrowia. Dzięki takim decyzjom, mniej lub bardziej świadomie, wspierają oni polską gospodarkę i rynek pracy ${ }^{41}$.

W kontekście polityki zdrowotnej jako takiej postulować należy z kolei przy okazji najbliższej reformy systemu ochrony zdrowia wprowadzenie finansowania za efekty zdrowotne - tylko takie, postępowe i nowe spojrzenie na system zdrowotny da szansę na jego dalszy i zrównoważony rozwój. Istotne dla zrównoważonego rozwoju systemu zdrowotnego jest wspieranie postępu i technologicznych przemian w kierunku systemu value based healthcare (medycyny opartej na wartości) i value based pricing (polityce cenowej dostosowanej do wartości); to taki system jest przyszłością medycyny. Powinno dojść do wypracowania własnego, dostosowanego do realiów danego kraju, sposobu uwzględnienia wartości płacenia za jakość i efekt w systemie zdrowia. Jest to jednak przede wszystkim wyzwanie dla państwa - konieczne jest bowiem branie pod uwagę relacji efekt-koszt terapii, gdzie mogą pojawić się sprzeczności pomiędzy beneficjentami schematu — pacjentami i producentami leków ${ }^{42}$.

37 Polskie przedsiębiorstwa farmaceutyczne są gotowe na to, by wprowadzać na rynek nowe leki generyczne czy biopodobne, a nawet do wytwarzania nowych leków, brakuje im jednak do tego realnych zachęt.

38 R. Budzisz, Podmioty administrujace ochrona zdrowia, [w:] System Prawa Medycznego. Pojęcie, źródta i zakres prawa medycznego, red. E. Zielińska, t. 1, Warszawa 2018, s. 691.

$39 \mathrm{~W}$ orzecznictwie sądów polskich wyrażony został także pogląd o braku doświadczenia rynkowego polskich konsumentów wynikającego z wieloletnich zaniedbań w edukacji konsumenckiej; por. przykładowo wyrok WSA w Warszawie z dnia 24 kwietnia 2007 roku, sygn. VI SA/Wa 126/07, CBOSA.

40 Prezes komitetu wykonawczego organizacji „Medicines for Europe”, Marc Alexander Mahl, wypowiedź w trakcie konferencji Medicines for Europe w dniu 12 czerwca 2019 roku w Warszawie, [w:] Z. Wojatsinski PZPPF, Nie wiadomo gdzie znikaja pieniadze uzyskane z niższej ceny leków biorównoważnych, www.rynekaptek.pl/marketing-i-zarzadzanie/pzppf-nie-wiadomo-gdzie-znikaja-pieniadze-uzyskane-z-nizszej-ceny-lekow-biorownowaznych (dostęp: 29.09.2019).

41 Około 80\% Polaków uważa, że rozwój przemysłu farmaceutycznego pozytywnie wpływa na polską gospodarkę, wiąże się z tworzeniem nowych miejsc pracy, postępem medycyny i innych dziedzin nauki, a także wzrostem PKB i dochodami państwa — badanie opinii publicznej wykonane na zlecenie Polskiego Związku Pracodawców Przemysłu Farmaceutycznego w kwietniu 2019 roku.

42 Por. H. Kaczmarczyk, [w:] Refundacja leków w Polsce. Wykladnia przepisów i efekty ich stosowania, red. H. Kaczmarczyk, Warszawa 2015, s. 28. 
Przedstawione w tym artykule problemy związane z polityką lekową państwa są wybranymi tylko zagadnieniami z tego zakresu. Miały uwidocznić one, w jaki sposób realizowana powinna być zasada zrównoważonego systemu ochrony zdrowia.

Zdrowie publiczne jest elementem zrównoważonego rozwoju i jako takie ma być zapewniane przez państwa dzięki zorganizowanym systemom opieki zdrowotnej. System ochrony zdrowia zbudowany jest z powiązanych ze sobą naczyń, niczym żywy organizm, w którym każdy z elementów wywiera bezpośredni wpływ na inny jego komponent. Działania rządu wspierające przedsiębiorców wpływają bezpośrednio na bezpieczeństwo zdrowotne pacjenta, decyzje pacjenta jako świadomego konsumenta na rynku zdrowia wspierają przedsiębiorców i polską gospodarkę. Zdrowy obywatel to filar całego systemu i polityki zdrowotnej państwa. Decyzje przedsiębiorców działających na rynku zdrowia, w tym na rynku farmaceutycznym, są newralgiczne dla wszystkich jego uczestników, wpływają na możliwość realizacji zadania publicznego, jakim jest ochrona zdrowia, wspierając w tym rząd oraz na zapewnienie bezpieczeństwa zdrowotnego w kraju, wspierając w tym jego obywateli. Dlatego tak jak w zdrowym, sprawnie funkcjonującym organizmie konieczne jest zapewnienie prawidłowego funkcjonowania każdej jego części, tak i w kwestii systemu ochrony zdrowia konieczna jest współpraca wszystkich jego elementów, dbałość o nie, współpraca, wola i zaangażowanie. Bo przecież — jak wskazano we wstępie - system ochrony zdrowia to spójna całość, której liczne, powiązane między sobą części, wspólnie oddziałując, wpływają pozytywnie na stan zdrowia populacji.

\section{Bibliografia}

Budzisz R., Podmioty administrujace ochrona zdrowia, [w:] System Prawa Medycznego. Pojęcie, źródta i zakres prawa medycznego, red. E. Zielińska, t. 1, Warszawa 2018.

Dercz M., Samorzad terytorialny w systemie ochrony zdrowia, Warszawa 2005.

Kiviniemi P., Riding the Waiver, „Mlex Magazine”, 2012, nr 9.

Komentarz do art. 68 Konstytucji RP, red. M. Safjan, L. Bosek, t. 1, Legalis 2016.

Kruszyński R., Obrót detalicznymi lekami. Zagadnienia prawne, Warszawa 2014.

Leowski J., Rola i miejsce państwa w systemie ochrony zdrowia, „Prawo i Medycyna” 2000, nr 6-7. Mazur-Wierzbicka E., Zdrowie publiczne jako element zrównoważonego rozwoju - analiza komparatywna. Polska na tle Unii Europejskiej, „Zeszyty Naukowe Uniwersytetu Ekonomicznego w Katowicach" 2017, nr 310.

Prawo farmaceutyczne. Zagadnienia regulacyjne i cywilnoprawne, red. M. Krekora, E. Traple, Warszawa 2008.

Prawo publiczne ochrony zdrowia, red. M. Dercz, H. Izdebski, T. Rek, Warszawa 2013.

Refundacja leków w Polsce. Wykładnia przepisów i efekty ich stosowania, red. H. Kaczmarczyk, Warszawa 2015.

Stefańczyk-Kaczmarzyk J., [w:] Prawo farmaceutyczne. Komentarz, red. M. Kondrat, Warszawa 2016. 
Świerczyński M., Obrót produktami leczniczymi oraz wymagania dotyczace podmiotów prowadzacych obrót, [w:] Prawo farmaceutyczne. Zagadnienia regulacyjne i cywilnoprawne, red. M. Krekora, E. Traple, Warszawa 2008.

Ustawa o refundacji leków, środków spożywczych specjalnego przeznaczenia żywieniowego oraz wyrobów medycznych. Komentarz, red. M. Pieklak, R. Stankiewicz, Warszawa 2014.

Wilk L., [w:] Prawo farmaceutyczne. Komentarz, red. L. Ogiegło, Warszawa 2018.

Włodarczyk C., Polityka zdrowotna w społeczeństwie demokratycznym, Łódź-Kraków 1996.

Włodarczyk C., Poździoch S., Systemy zdrowotne. Zarys problematyki, Kraków 2001.

Zdrowie publiczne, red. M. Latalski, Lublin 1999.

\section{A sustainable healthcare system - considerations in the context of the current drugs policy of the state}

Summary

Sustainable and balanced development is an element of all European Union policies and thus also the national policies of member states, including Poland. Its integral and important part is public health. The health of citizens is primarily the goal of the health policy of the state and its drugs policy. The tool through which these policies are implemented is the health care system, whose efficiency also depends on other systems operating in the country, because it is an integral part of the entire economic, political, and social system. Only balancing health needs, financial and economic capabilities of the state, and the participation of a non-public entities healthcare system can bring success in the field of public health. Deficiencies in this area have been particularly evident recently in the field of drugs safety of Polish citizens. Therefore, the main goal of the article will be to assess legislative progress on issues relevant to drugs policy and, consequently, the entire health policy of the country and public health as a component of sustainable development.

Keywords: sustainable development, healthcare system, health policy, drug policy. 